\title{
CREATION OF AN ENVIRONMENTAL MONITORING OBSERVATORY FOR COASTAL MANAGEMENT IN THE MUNICIPALITY OF ITAGUAÍ, BRAZIL
}

\author{
NELSON M. CORDEIRO \& ITALO L. AMARAL \\ Federal Center for Technological Education, Celso Suckow da Fonseca, Brazil
}

\begin{abstract}
This project aims to propose the creation of a socio-environmental observatory which will serve as a system of information and it will incorporate data about technical specifications, business partners, environmental impacts and social conflicts in the coastal zone of the municipality of Itaguaí, on the green coast of Rio de Janeiro. The significant increase in the number of local enterprises which are sometimes not set up in an ecological way is remarkable. Our work includes the use of a PSR Model (Pressure-Status-Response) serving as a structure that, along with the field research conducted, defines the sustainability indicators of socio-economic sectors as pressure indicators that characterize the pressures on environmental systems such as: emission of contaminants, technological efficiency, intervention in the territory and environmental impact - status indicators that reflect the quality of the environment in a given space/time and response indicators that assess the society's responses to change and environmental concerns. It was found that the increase in the number of companies in the maritime area of operation can generate more than a large environmental impact, but a significant social impact. Studies of associations and local companies say that the main problem of the region is not the emergence and development of enterprises, but the lack of a structured coastal management. Among the problems encountered, it highlights the increased mortality of marine animals and the excessive movement of vessels, which, in addition to harming the marine environment, is affecting the generation of income that is based on fishing. It was concluded that it is extremely important to be clear that the local government spheres can not be considered in isolation, since the efficience of local management depends on the ability to mobilize resources and joint actors, governmental or not, aimed at increasing the local governance and thus ensure their assignments, the observatory would meet this need.

Keywords: environment, environmental planning, environmental management, environmental monitoring, environmental education, coastal zone, coastal management, urban planning, territoriality, sustainable development.
\end{abstract}

\section{INTRODUCTION}

Societies characterized by high social inequalities and marked by perverse modernization processes need to protect their natural patrimony and, at the same time, increase ways of improving the quality of life of the population. This presupposes a rational and democratic use of its resources, which implies a socially fair and environmentally appropriate planning of the use of the places.

We have the knowledge and technology to separate us from the old paradigm, which increasingly directs us to a bleak future. Therefore, it is necessary to denounce the exhaustion of an increasingly utilitarian model, giving rise to a new direction for the society in the pursuit of sustainability.

Sustainability is a slogan in this scenario of searching for a value system that perpetuates the threshold of this new civilizing milestone. Sustainable development was established through the United Nations, shortly before Rio-92, through the Brundtland Report, as a development that meets the needs of the present without compromising the ability of future generations. 
Ignacy Sachs [1], one of the founders of sustainable development theory, states that: "Sustainability is not only based on the vision of environmental sustainability, but on several dimensions". Sachs formulated the basic principles for sustainable development, which were represented in six dimensions: social, economic, ecological, spatial, cultural and political.

This article aims to present the proposal to create a socio-environmental observatory on the coast of Itaguaí, on the green coast of the State of Rio de Janeiro, which as an information system will incorporate data on technical specifications, corporate articulations, Environmental impacts, social pendencies, conflicts and spatial rearrangements engendered in the logistic uses of the coastal border in this place and its territorial connections

\section{METHODOLOGY}

This work uses the Pressure-State-Response (PSR) Model as a methodological reference, which, according to the classification of the Organization for Economic Cooperation and Development, will serve as a basis for the definition of the sustainability indicators of the socioeconomic sectors.

According to this model, environmental indicators can be systematized into three key groups of indicators: 1) Pressure Indicators - characterize the pressures on environmental systems and can be translated by indicators of emission of contaminants, technological efficiency, intervention in the territory and environmental impact; 2) State Indicators reflect the quality of the environment in a given space/time horizon; indicators of sensitivity, risk and environmental quality; and 3) Response Indicators - evaluate society's responses to environmental changes and concerns, as well as adherence to programs and/or implementation of environmental measures; social inclusion, awareness and activities of important social groups can be included in this group.

For the characterization of local governance, a socio-environmental questionnaire and group dynamics were applied to all the main actors involved in the process. This data will be stored in a specific database in order to make feasible the construction of scenarios that allow us to evaluate each result.

\subsection{Technical cooperation and partnerships}

For the operation of this observatory, a series of agreements of technical cooperation and of partnerships in the project will be realized, as follows:

- Industrial Ports: the activities inherent to a port, such as dredging maintenance of access channels because of the intense movement of large vessels in the Sepetiba Bay, and the establishment of areas of smelting and exclusion for its operation, makes this sector an important component to be considered in the definition of zoning and coastal planning.

- Fishing Sector (representations): in order to make possible a more cohesive reading and interpretation of the context in which the fishing sector of the region is inserted.

- Military: Naval Base in Restinga de Marambaia and the future Naval Base of PROSUB in Madeira Island.

- Search:

- Federal Rural University of Rio de Janeiro, Laboratory of Bioacoustics and Ecology of Cetaceans; 
- State University of Rio de Janeiro - Institute of Oceanography, Department of Biological Oceanography; Instituto Boto Cinza;

- Pro-Sepetiba Foundation;

- Gota D’água de Proteção à Natureza Group, a non-governmental organization of socio-environmentalist character, with activities related to the research of models for sustainable development programs, especially in the aquaculture segment.

- Tourism: the tourism activities of Madeira, Itacuruçá and Coroa Grande focus especially on business tourism, while on the islands, consumption is focused on summer tourism, with the use of boats for leisure. In this way, one can conclude that the tourism sector directly related to the use of the bay is that of the islands.

- Maritime Authority: according to the Law of Ports (Law 8.630 / 1993), it is up to the maritime authority to:

- establish, maintain and operate the beacons of the access channel and the evolution basin of the port;

○ delimit the areas of anchorage, loading and unloading grounds, sanitary inspection and maritime police, as well as platforms and other special vessels, warships and submarines, ships under repair or awaiting mooring, and ships with flammable cargoes or explosives;

- establish and disseminate the maximum draft of the ships' operations, based on the bathymetric surveys carried out under their responsibility;

establish and disclose the maximum gross capacity and the maximum dimensions of the vessels to be transported, depending on the limitations and physical characteristics of the port dock.

Thus, although it is not a user sector of the Bay of Sepetiba, it is the responsible agent for the regulation of its use, functioning as a very important actor in the zoning.

\section{THEORETICAL REVIEW}

Knowledge of the seas is increasingly vital for thinking about the future. Among the various issues in focus, one of immediate social relevance is related to climate change arising from global warming and its effect on rapidly rising sea levels. Thus, the present time indicates the need for the rational and integrated management of coastal spaces. Changes in the coastal and marine environment can produce major impacts. The production of goods and services by the oceans may be directly impacted by other anthropogenic activities, even when there is no change in the state of the environment. This can happen when different types of marine uses are shared with each other.

The area of the coastal zone in Brazil is about $8500 \mathrm{~km}$ along the coast, where more than a quarter of the Brazilian population is concentrated, with a population density of $87 \mathrm{hab} / \mathrm{Km}^{2}$, five times higher than the national average [2]. This strip of coastal land corresponds to less than $2 \%$ of the terrestrial territory and shelters a population of more than 4 billion people.

The International Community of Marine Resources defines that the coastal zone [3] covers a variety of ecosystems of high environmental relevance, constituting a geographic space characterized by the interaction of the sea, air and land, whose diversity is marked by the transition in: land area (parts of the continent formed by municipalities that suffer direct influence from the phenomena that occurs in the coastal zone); and maritime area (range extending up to 12 nautical miles established in accordance with the UN Convention), with interactions that give it a character of fragility. 
The issue of environmental vulnerability will be understood as ".. the greater or lesser susceptibility of an environment to a potential impact caused by any anthropic use" [4].

In order to promote the integrated management of the coastal and marine zone, Brazil has the National Coastal Management Program [5], whose objective is to operationalize the National Coastal Management Plan (PNGC) [6], in order to guarantee its sustainable use, through control, protection, preservation and recovery of natural resources and coastal ecosystems. Throughout the 20 years of the PNGC, there was a strong investment from the Ministry of the Environment (MMA) for the 17 Brazilian coastal states to structure their state coastal management plans.

Gusmão [7] reports that the National Coastal Management Plan aims at establishing instruments focused at guiding the use and occupation of the coastal zone, as well as promoting an economically and environmentally viable development.

The Sole Paragraph of art. 8 of Law 7.661/88 summoned universities and other cultural, scientific and technological institutions to submit to the subsystem of coastal management, data related to natural, historical, ethnic and cultural patrimony, environmental quality and studies of impacts on the environment of the Coastal Zone. Thus, organisms (observatories) emerge to concentrate and disseminate information through specific, synthetic, credible and contextualized contents.

\section{ANALYSIS AND DISCUSSION}

\subsection{Itaguaí: the fastest growing municipality in the state of Rio de Janeiro.}

Data from FIRJAN [8] indicate that the municipality of Itaguaí is the fastest growing in the State of Rio de Janeiro. This growth has been directed to the local coastal region, which presents strategic global location, competitiveness and integration of several ventures in its area of influence. The municipality of Itaguaí is characterized as an urban population, since $96 \%$ of its resident population lives in urban areas. According to the Gênesis Institute (PUC-RIO) [9], "in terms of economy, in 2012 the tertiary sector was still the most relevant of Itaguaí's economy. $81.40 \%$ refers to the economic participation of the services sector in the gross value added of the municipality's GDP. The secondary sector (Industry) comes next with $17.94 \%$ of economic participation in the gross value added of GDP. In turn, agriculture and livestock yields only $0.66 \%$ of the municipality's GDP”.

The economic changes in the municipality were quite significant in recent years. According to the Human Development Atlas of 2013, the average per capita income of the municipality of Itaguaí has increased by $95.70 \%$ in the last two decades, from $\mathrm{R} \$ 324.74$ in 1991 to $\mathrm{R} \$ 635.50$ in 2010 . The family rate considered in extreme poverty went from $11.65 \%$ in 1991 to $5.05 \%$ in 2010 .

\subsection{Metropolitan Arc}

The Metropolitan Arc, the main link of COMPERJ, Rio de Janeiro Petrochemical Complex from Itaboraí to Itaguaí Port, as a logistics strategy increases its competitiveness, and eventual terminals of agricultural and liquid bulk attract part of the future additional cargo of Santos and Tubarão ports. Similarly, the construction of the Arc allows in optimized scenarios for this port to absorb more than 500,000 tons of future road flows from other ports such as Santos, Rio de Janeiro and Praia Mole. Due to such a large and accelerated change in the municipality of Itaguaí, the presentation of a proposal or model of coastal 
management integrated with the socioeconomic activities dependent on the coastal zone becomes necessary.

\subsection{Areas of conflict}

Associations for strengthening artisanal fisheries and mariculture have pointed out some conflicting uses in the region studied:

- Overlapping areas with fishing areas and areas of aggregation of the Gray Boto (Solatea guianensis), also harming tourism;

- Areas of exclusion are increasing due to companies consequently reducing fishing areas, collecting shellfish and increasing fishing routes.

This is one of the most conflicting issues between fishermen in the region and other sectors. These areas, created by ports, shipping channels and military areas, not only reduce fishing and shellfish areas, but also increase access routes to fishing areas.

\subsection{Field research}

Through a field survey carried out in the region, relevant information has been obtained from some mapped associations which are sometimes not noticed by those who do not live or work on the green coast.

The increase in the number of companies or the increase in the maritime area of these companies, besides generating a great environmental impact, have a significant social impact. Leonardo Flach [10], representative of the Boto Cinza Institute (IBC), affirms that the main problem in the region studied is not exclusively the emergence and development of companies, but the lack of planning and control that causes the most disturbing social and environmental imbalances. Among the problems verified by the Institute, we highlight the increase in the mortality of porpoises, since a data survey revealed that between 2005 and 2009 there were 2.6 dead whales per month, and from January 2014 to May 20155 to 6 dead porpoises were found per month; a concern for the Institute is that with the increase of the movement of boats, the intensity of sound interferences in the depth of the sea increases, causing stress to the animals since they must increase their habitual sound frequencies for communicating.

For associations interviewed, the implantation of companies without good environmental planning is causing a decrease in the Atlantic Forest (an area of environmental preservation) and the mangrove that helps to contain pollution. There is currently a risk of extinguishing the local estuary, as the water course is being modified, which could seriously affect marine biodiversity.

As noted earlier, local associations affirm that not only marine diversity is affected but also the population. The decrease of the fishing regions that are being occupied by the movement of the vessels generate a greater fishing effort for the artisanal fisherman. Sérgio Hiroshi, vice-president of the Association of Fishermen and Farmers of Madeira (APLIM), says that the city is losing a traditional profession because of the unbridled development process, transforming it into a dormitory city (personal communication, 3 August 2015).

Research shows a deficiency in the educational system and, as a result, companies in the region tend to hire professionals from other cities because local professionals do not meet the demand. However, according to José Carlos Naipe (personal communication, 13 July 2015), the president of the Association of Maricultures of the Green Coast of Itaguaí, the 
region faces educational problems not only due to the inefficiency of the public administration, but also because of cultural issues, where it is common for children to drop out of school for fishing practice. Sérgio Hiroshi, vice president of the Association of Fishermen and Farmers of Island of Madeira, points out the deficiency in public transport, which he says exacerbates local problems related to education, since students find it difficult to move to educational institutions.

However, some projects have been proposed, such as "the creation of the school ferry, which will be built to meet the educational need of the region, however the project is already behind schedule. The ferry is still in Minas being built" as Naipe (personal communication, 13 July 2015) said in 2015.

For the Association of Maricultures of the Green Coast of Itaguaí, some simple changes could generate great results; for example, the extraction of the carrageenan, powder extracted from some species of red algae, in the region would be a great step for the local maricultures and fishermen, considering that today Brazil imports $95 \%$ of the carrageenan.

For the Boto Cinza Institute, an important step for growth and adaptation to local changes would be encouraging an alternative income for fishermen, and for this the institute is conducting a survey of non-target species to identify species that fall into the net and are not harnessed and species that fall into the net and are harnessed. The proposal is not to discard some fish that do not sell much; for example, one should file fish and sell it for public school snacks, making fish sausages, burgers, etc.

\subsection{Creation of the observatory}

Observatories can be defined as entities "whose activity consists on compiling information from a social sector, diagnosing their situation, forecasting their evolution and producing reports that serve as a basis for decision-making in response to the demands of this social sector" [11], a "structure of monitoring and monitoring of social reality" and, also "social technology of information and knowledge management" [12]. Or "space of transparency on social phenomena".

Given the importance of environmental issues, there is a growing need to create observatories to monitor, control and disseminate the "state of the environment". According to the Agenda 21 [13], although there is already a considerable amount of data, it is necessary to collect more and different types in order to indicate "the condition and trends of ecosystems, natural resources, pollution and socio-environmental variables of Planet" [14]. The document points out that countries should "increase their capacity to receive, store and recover, contribute, disseminate and use relevant information on the environment and development, as well as provide them with adequate public access, by providing technology and training to Establish local information services" (p. 350). It is in this context that socio-environmental and sustainability observatories emerge and build their trajectory.

The creation of this socio-environmental observatory in the coastal region of the municipality of Itaguaí has added actions along with other institutions and communities in the commitment to make transparent the participation of diverse perspectives, making possible the democratic practice and interventions before the public policies presented or necessary for the sector.

In this sense, it is necessary to instrumentalize a database on the coastal zoning of the municipality of Itaguaí, harboring and re-feeding the information recorded uninterruptedly. It will, therefore, seek to provide up-to-date and detailed information that will allow a greater debate in society about the problems within the coastal region and its public 
regulatory policies. The required information is as follows: (a) technical; (b) economic; (c) legal; (d) environmental; (e) social; (f) bibliographic references, among others. The main innovation of the observatory is to enable different social actors, governmental and nongovernmental organizations, researchers and activists to be able to easily access a database with relevant information needed to plan, advise and discuss individual reparation or collective impacts in the coastal region of the municipality of Itaguaí.

\section{CONCLUSIONS}

From all the discussions above, it is concluded that it is extremely important to be clear that the spheres of local power can not be considered in isolation, since the efficiency of this local management depends on the capacity to mobilize resources and articulate actors, governmental or non-governmental, at different scales, with a view to broadening local governance and thus guaranteeing its attributions.

The National Coastal Management Plan is a public policy in full development, and that presents exceptional efforts of construction by the federal and state governments; it seeks favorable conditions and participatory adoption in the discussion in order to maintain the integrity of ecosystems and the planning of the use of natural resources in a sustainable way. The challenge of sustainable development is, above all, a political and exercise problem. Power, which puts into question the matter of political-administrative institutions, participation and the political process; hence, the need to combine efforts in order to broadly manage the information process, with a view to mobilizing actors in this great game of forces.

\section{REFERENCES}

[1] Sachs, I., Estratégias de Transição para o Século XXI. Desenvolvimento e Meio Ambiente, São Paulo: Studio Nobel/Fundap, 103 pp., 1993.

[2] IBGE, Instituto Brasileiro de Geografia e Estatística, Censo demográfico. 2000. http://www.ibge.gov.br/home/estatistica/populacao/censo2000. Accessed on: 20 Apr. 2008.

[3] Tagliani, P.R.T., Estudo ambiental para obtenção do licenciamento prévio para instalação do parque eólico piloto de rio grande. Relatório Técnico, 2003.

[4] MMA, http://www.mma.gov.br/images/arquivo/80033/0.PNGCII97\%20Resolucao05 97.CIRM.pdf, 2016.

[5] MMA, O Plano Nacional De Gerenciamento Costeiro, http://www.mma.gov.br/ port/sqa/projeto/gerco/planocac.html. Accessed on: 4 Oct. 2013.

[6] Instituto Pharos, Plano nacional de gerenciamento costeiro ii, http://www.institutopharos.org/legislacao/legislacao2.html. Accessed on: 4 Oct. 2013.

[7] Gusmão, P.P., Elementos para a construção de uma agenda para a gestão ambiental da área de influência do porto de Itaguaí - RJ. Elements for the elaboration of an environmental management agenda in the local hinterland of the port of Itaguaí, RJ Confins: Paris, pp. 1-15, 2012.

[8] FIRJAN, Avaliação dos impactos logísticos e socioeconômicos da implantação do arco metropolitano do Rio de Janeiro, www.firjan.org.br/lumis/portal/file/ filedownload.jsp?fileid. Accessed on: 20 Oct. 2013.

[9] Instituto Gênesis, PUC, Diagnóstico do perfil empreendedor de empreendimentos sociais dos territórios dos muncípios de Mangaratiba e Itaguaí, p. 43, 2015. 
104 Coastal Cities and their Sustainable Future II

[10] Flach, L., Densidade, tamanho populacional e distribuição do boto-cinza (sotalia guianensis) (Van Benéden, 1864), na Baía de Sepetiba, estado do Rio de Janeiro, 2004.

[11] Enjuto, N., Razón de ser de los observatórios, observatorio del voluntariado, Observando observatories. Nuevos agentes en el tercer sector? Plataforma del Voluntariado de España: Madrid, pp. 10-17, 2010.

[12] Iracheta Cenecorta, A., Observar la ciudad cientificamente para entender más y actuar melhor. Cuadernos Para el Desarrollo Social, 2(3), pp. 41-58, 2004.

[13] Agenda 21 Brasileira, Ações prioritárias/comissão de políticas de desenvolvimento sustentável e da agenda 21 nacional, Ministério do Meio Ambiente: Brazil, 158 pp., 2004.

[14] United Nations, p. 346, 1992. 